\title{
Differences in Actin Localization during Bud and Hypha Formation in the Yeast Candida albicans
}

\author{
By JULIA M. ANDERSON AND DAVID R. SOLL* \\ Department of Biology, University of Iowa, Iowa City, Iowa 52242, USA
}

(Received 22 November 1985; revised 17 February 1986)

\begin{abstract}
Stationary phase cells of Candida albicans can form either a bud or a hypha, depending upon the $\mathrm{pH}$ of the medium into which they are released. At low $\mathrm{pH}$, cells form an ellipsoidal bud and at high $\mathrm{pH}$, cells form an elongated hypha. By staining cells with rhodamine-conjugated phalloidin, we have compared the dynamics of actin localization during the formation of buds and hyphae. Before evagination, actin granules were distributed throughout the cytoplasmic cortex in both budding and hypha-forming cells. Just before evagination, actin granules clustered at the site of evagination, then filled the early evagination in both budding and hyphaforming cells. With continued bud growth, the actin granules then redistributed throughout the cytoplasmic cortex. In marked contrast, with continued hyphal growth, the majority of actin granules clustered at the hyphal apex. This distinct difference in actin granule localization may be related to the distinct differences in the expansion zones of the cell wall recently demonstrated between growing buds and hyphae. The spatial and temporal dynamics of the large neck actin granules and of actin fibres are also described.
\end{abstract}

\section{INTRODUCTION}

Immunofluorescent and fluorochrome-labelled phalloidin staining have shown that dramatic changes in actin localization accompany the budding cycle of Saccharomyces uvarum and S. cerevisiae (Kilmartin \& Adams, 1984; Adams \& Pringle, 1984). Actin granules cluster in the peripheral cytoplasm at the site of evagination and in the ensuing small and medium sized buds, while actin fibres align themselves in the mother cell-bud axis. In mutants which form elongated buds, actin patches are evident in the bud apex. At the end of a cell cycle, actin appears to cluster or form a band at the mother cell-bud junction. Several aspects of this complex behaviour (Kilmartin \& Adams, 1984; Adams \& Pringle, 1984) and the effects of mutations in the essential actin structural gene of $S$. cerevisiae (Novick \& Botstein, 1985) suggest that actin localization plays a role in cell wall deposition and growth.

Recently, it was demonstrated that spatial, temporal and quantitative differences in the zones of cell wall expansion in the dimorphic yeast Candida albicans are basic to the genesis of the alternative bud and hyphal phenotypes (Staebell \& Soll, 1985; Soll et al., 1985). During initial bud growth, a small apical growth zone accounts for two-thirds of total wall expansion and general growth throughout the wall accounts for the remaining one-third. When a bud has grown to two-thirds of its final circumference, the apical growth zone shuts down completely and general growth completes bud expansion. In marked contrast, during hyphal growth the apical component accounts for more than $95 \%$ of wall expansion and does not shut down as long as the daughter cell grows in the hyphal form (Staebell \& Soll, 1985; Soll et al., 1985). If actin localization is involved in the zones of wall expansion and the differences in the shape of the daughter cells, then one would expect the distribution of actin to differ between a growing bud and a growing hypha. As we shall demonstrate in this report, this is indeed the case. 


\section{METHODS}

Growth and maintenance of stock cultures. Stock cultures of wild-type strain 3153A of Candida albicans were maintained by previously described methods (Soll \& Bedell, 1978; Soll et al., 1978; Bedell et al., 1980). To initiate an experiment, cells from a clone maintained on agar were suspended in $25 \mathrm{ml}$ defined medium (Lee et al., 1975) supplemented with $70 \mu \mathrm{g}$ arginine $\mathrm{ml}^{-1}$ and $0.1 \mu \mathrm{M}$-zinc sulphate in $125 \mathrm{ml}$ glass Erlenmeyer flasks (Bedell \& Soll, 1979; Soll et al., 1981 ; Soll, $1985 a$; Anderson \& Soll, 1984). Cultures were rotated at 200 r.p.m. at $25^{\circ}$ C. Cells from stationary phase cultures were diluted into a second growth flask and incubated under the same conditions before use.

Induction of synchronous bud or hypha formation by the regime of pH-regulated dimorphism. The methods for initiating synchronous bud or hypha (mycelium) formation were similar to those previously described (Mitchell \& Soll, 1979 $a, b$; Buffo et al., 1984). In brief, cell cultures were grown to stationary phase. After 24 to $36 \mathrm{~h}$ in stationary phase, cells were lightly sonicated and resuspended in $25 \mathrm{ml}$ fresh nutrient medium preheated to $37^{\circ} \mathrm{C}$. The cell concentration ranged between 1 and $5 \times 10^{6}$ spheres $\mathrm{ml}^{-1}$. To induce synchronous bud formation, the $\mathrm{pH}$ of the medium was 4.5 ('low pH'), and to induce synchronous hypha formation, the $\mathrm{pH}$ of the medium was 6.8 ('high pH'). In either case, cultures were rotated at 200 r.p.m. at $37^{\circ} \mathrm{C}$.

Actin staining with tagged phalloidin. Stationary phase cells were released into fresh nutrient medium at low $\mathrm{pH}$ or high $\mathrm{pH}$ at $37^{\circ} \mathrm{C}$ and incubated as described in the previous section. A flask containing $25 \mathrm{ml}$ cell suspension was removed at $100,120,140,160$ and $180 \mathrm{~min}$, and the cells were collected on individual Millipore filters $(0.45 \mu \mathrm{m}$ pore size). The cell filtrates were washed with $50 \mathrm{ml}$ distilled water and within $1 \mathrm{~min}$ of harvesting fixed in formaldehyde according to the methods of Adams \& Pringle (1984). Cells were resuspended and incubated in $5 \mathrm{ml}$ solution A ( $35 \mathrm{~mm}$-potassium phosphate buffer, pH 6.8, $0.5 \mathrm{mM}-\mathrm{MgCl}_{2}$ ) containing $4 \%(\mathrm{v} / \mathrm{v})$ formaldehyde for $2 \mathrm{~h}$ at $24^{\circ} \mathrm{C}$. Cells were then pelleted, washed twice in solution A lacking formaldehyde and once in solution B (solution A containing $1.2 \mathrm{M}$-sorbitol), and incubated in $55 \mu \mathrm{l}$ glusulase (Dupont Pharmaceuticals) plus $1 \mathrm{ml}$ solution $B$ for $2 \mathrm{~h}$ at $37^{\circ} \mathrm{C}$. After glusulase treatment, cells were washed twice in solution $\mathrm{B}$ and then resuspended in $3 \mathrm{ml} \mathrm{0.2 \%} \mathrm{Triton} \mathrm{X-100} \mathrm{in} \mathrm{PBS} \mathrm{(137} \mathrm{mM-NaCl,} 2.7 \mathrm{~mm}-\mathrm{KCl}, 8.0 \mathrm{mM}-\mathrm{Na}_{2} \mathrm{HPO}_{4}, 1.5 \mathrm{mM}-\mathrm{KH}_{2} \mathrm{PO}_{4}$ adjusted to pH 7.3) for $10 \mathrm{~min}$. Cells were then washed twice in PBS, resuspended in $600 \mu 1$ PBS containing $1 \mathrm{mg} \mathrm{NaN}_{3} \mathrm{ml}^{-1}$ and stored at $4^{\circ} \mathrm{C}$. Cells could be stored in this form for as long as one week before staining.

To stain cells, $200 \mu \mathrm{l}$ of the above cell suspension was incubated with $1 \mu \mathrm{l}$ of a stock solution of $0.4 \mathrm{mg}$ tetramethylrhodaminylphalloidin $\mathrm{ml}^{-1}$ ( $\mathrm{Rh}$-phalloidin; a generous gift of $\mathrm{Dr} \mathrm{T}$. Wieland, Max-Planck Institute for Medical Research, Heidelberg, FRG) in methanol for $2 \mathrm{~h}$ in the dark. For samples where clumping was a problem (e.g. after 140,160 and $180 \mathrm{~min}$ incubation at $\mathrm{pH} \mathrm{6.8),} \mathrm{cells} \mathrm{were} \mathrm{lightly} \mathrm{sonicated} \mathrm{before} \mathrm{staining,} \mathrm{and}$ vortexed every 15 min during the staining period. After staining, the cells were washed five times in PBS and the final cell pellet was resuspended in mounting medium containing $100 \mathrm{mg} p$-phenylenediamine dissolved in $10 \mathrm{ml}$ PBS and adjusted to $\mathrm{pH} 9$ with $0.1 \mathrm{M}-\mathrm{NaOH}$. Glycerol $(90 \mathrm{ml})$ was then added and the solution stored at $-20^{\circ} \mathrm{C}$. Clumped cells in mounting medium were lightly sonicated before placing on a glass slide.

Cells were viewed and photographed with either a Leitz SM-LUX or a Zeiss Photomicroscope III equipped for rhodamine epi-illumination fluorescence microscopy. A $100 \mathrm{~W}$ super pressure mercury $\mathrm{HBO} \mathrm{w} / 2$ lamp (Osram) was used in both microscopes and a $63 \times$ NA 1.3 fluorescence objective in the Leitz microscope and a $63 \times$ NA1.4 Planapo objective in the Zeiss microscope. Photographs were made on Kodak Tri-X pan film or Kodak Plus-X pan film. Film was developed in Diafine according to the manufacturers' instructions.

\section{RESULTS}

\section{pH-regulated dimorphism}

To obtain semi-synchronized populations of budding or hypha-forming cells, we used the experimental regime of 'pH-regulated dimorphism' (Soll et al., 1981; Buffo et al., 1984; Soll, $1985 \mathrm{~b}$ ). In this method, stationary phase cells were diluted into fresh medium at $37^{\circ} \mathrm{C}, \mathrm{pH} 4.5$

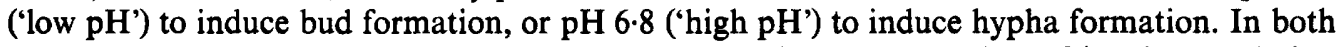
cases, cells began to evaginate after $100 \mathrm{~min}$. By approximately $135 \mathrm{~min}, 50 \%$ of the population had evaginated at $\mathrm{pH} 4.5$, and by $145 \mathrm{~min}, 50 \%$ had evaginated at $\mathrm{pH} 6.8$. At $\mathrm{pH} 4.5$, each evagination expanded into a ellipsoidal daughter cell, or bud, which grew to a maximum bud volume before the mother cell and then the bud formed secondary buds (Herman \& Soll, 1984). At $\mathrm{pH} 6.8$, each evagination grew as an elongated tube, or hypha, without secondary evaginations as long as the conditions supported hyphal growth (Mitchell \& Soll, 1979a).

\section{Actin localization before evagination}

Less than $8 \%$ of the initial stationary phase cell population stained with phalloidin, which is a relatively specific stain for filamentous actin (Wulf et al., 1979). After $30 \mathrm{~min}$ in fresh medium at 
Table 1. Proportions of pre-evaginated cells exhibiting different patterns of actin localization during bud ( $p H 4.5)$ and hypha ( $p H 6.8)$ formation

\begin{abstract}
These data are the combined results of four experiments. $n$ is the total number of cells scored. In all experiments, stationary phase cells were diluted into fresh medium at $\mathrm{pH} 4.5$ to induce bud formation and at pH 6.8 to induce hypha formation. Unbudded 'singlets' were scored for phalloidin-stained actin localization at 100,120,140,160 and $180 \mathrm{~min}$ after dilution (time zero). The kinetics of evagination in all experiments were similar. The average times of evagination in all experiments was close to $135 \mathrm{~min}$. See Fig. 1 for diagrams of major patterns.
\end{abstract}

Pattern

Edge granules
with fibres
without fibres
Clustered granules
with directed fibres
without fibres
Clustered granules, edge granules
with fibres
without fibres
Generally distributed granules
with fibres
without fibres
Generally distributed granules, edge granules
with fibres
without fibres
Fibres only
Other
Total with edge granules
Total with clustered granules
Total with generally distributed granules
(a) Budding cells $(n=490)$ Percentage with pattern

54
38
16
23
22
1
6
4
2
3
2
1
3
1
2
10
0
64
29
7

(b) Hypha-forming cells $(n=399)$ Percentage with pattern

either $\mathrm{pH}$, the same was still true, indicating that there is little organized actin in stationary phase cells or in cells early in the pre-evagination period. However, after $100 \mathrm{~min}$ in fresh medium, just before evagination at either $\mathrm{pH}$, well over $50 \%$ of the total cell population exhibited organized staining in individual preparations, and in the best preparations, the figure was over $95 \%$.

Since the cell populations at either $\mathrm{pH}$ evaginated semi-synchronously between 100 and $180 \mathrm{~min}$ of incubation, a decreasing proportion of the cell population was composed of unbudded cells (pre-evagination cells) with time. We first analysed the patterns of stained actin for all unbudded cells examined between 100 and $180 \mathrm{~min}$ of incubation. The proportions of these cells exhibiting the different discernible patterns are presented in Table 1 for cells at $(a)$ low $\mathrm{pH}$ and $(b)$ high $\mathrm{pH}$. A little more than half of the stained singlets at both low and high $\mathrm{pH}$ contained actin granules confined to the outer shell, or edge, of the cytoplasm (Fig. 1 $a$; see example in Fig. 2a). The majority of cells with this pattern, referred to as 'edge granules', also contained randomly oriented fibres at both $\mathrm{pH}$ values. In contrast, roughly one-third of stained singlets at both low and high $\mathrm{pH}$ contained a single cluster of granules localized in a small region of the outer shell of the cytoplasm (Fig. $1 b$ ). The majority of these cells contained cytoplasmic fibres, in all cases oriented towards the granule cluster. Roughly $10 \%$ of unevaginated cells at both $\mathrm{pH}$ values exhibited cytoplasmic fibres but no granules, and close to this percentage contained granules generally distributed throughout the cytoplasm (Table 1).

The proportions of unbudded cells exhibiting the different staining patterns at 100,120 and 140 , and $160 \mathrm{~min}$ were also individually assessed (data not presented). One trend was evident. The proportion of unbudded cells at both $\mathrm{pH}$ values with edge granules and no visible fibres decreased with time while the proportions of unbudded cells with fibres only or with clustered granules and fibres increased with time. 


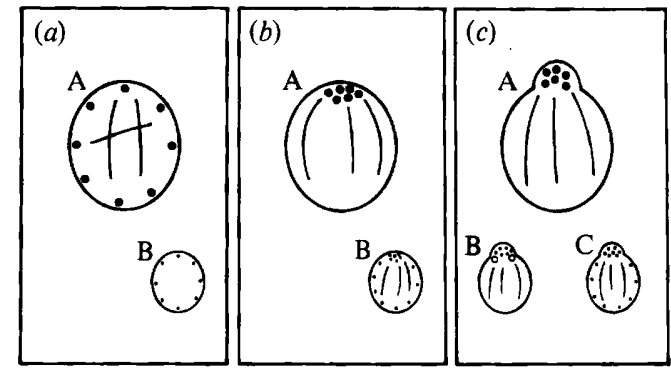

Fig. 1. Diagrams of the major patterns of phalloidin-stained actin in unbudded singlets at either low (4.5) or high (6.8) $\mathrm{pH}$ before evagination $(a, b)$ and just after evagination $(c)$. (a) Edge granules in a preevaginated cell with (A) or without (B) obvious cytoplasmic fibres; $(b)$ granule cluster in a preevaginated cell without (A) or with (B) edge granules; (c) granule cluster in an early evagination (A), with large neck granules (B), or with edge granules (C). A is the predominant phenotype and $B$ and $C$ are the less frequent phenotypes. Note that the fibres are randomly distributed in the predominant edge dot phenotype in unevaginated cells $(a)$, but are directed towards the cluster in all cells with clustered granules $(b, c)$. See Table 1 for the proportions of pre-evaginated cells exhibiting the different patterns of actin localization.

Table 2. Proportions of early evaginating cells exhibiting different patterns of actin localization during bud ( $p H 4.5)$ and hypha ( $p H$ 6.8) formation

These data are the combined results of four experiments and are summed for early evaginating cells at $100,120,140,160$ and $180 \mathrm{~min}$. See Fig. $1(c)$ for diagrams of major patterns. $n$ is the total number of cells scored.

Pattern

Clustered granules

Clustered granules, large neck granules

Clustered granules, edge granules in mother cell

Clustered granules, edge granules in mother cell, large neck granules

Other

Total with clustered granules

Total with edge granules in mother cell (a) Budding cells

$(n=132)$

Percentage

with pattern

$\begin{array}{rr}41 & 50 \\ 36 & 31 \\ 14 & 11 \\ 4 & 4 \\ & \\ 5 & 4 \\ 95 & 96 \\ 23 & 16\end{array}$

\section{Actin localization during early evagination}

The first indication of bud or hypha formation involves a single outpocketing or evagination of the cell wall. The combined data for cells with incipient evaginations between 100 and 180 min of incubation are presented in Table 2 for low and high $\mathrm{pH}$ cultures. Unlike cells before evagination, virtually the entire population of early evaginated cells at low $\mathrm{pH}(95 \%)$ and high $\mathrm{pH}(96 \%)$ contained clustered granules in the evagination (Fig. $1 c$; see example in Figs $2 c$ and $3 a$, respectively). Approximately one-fifth of the population in low and high $\mathrm{pH}$ cultures also contained edge granules in the mother cell. Over $90 \%$ of the cells with clustered granules contained stained fibres (Fig. $2 c$ ) in the mother cell, and in all cases the fibres were directed towards the cluster, or evagination.

A new actin condensation was also visible at the junction of the mother cell and evagination in over one-third of the cells at low and high pH (Table 2). This structure usually appeared to be composed of two large granules (Fig. $2 b$ ), or to a lesser extent as a densely staining bar, and will be referred to as 'large neck granules'. In either stained form, this structure was usually larger, or more intensely staining, than the individual granules in the edge or cluster pattern.

Several differences in actin distribution between pre-evaginated and evaginated cells can be considered in terms of temporal transitions. First, edge granules were observed in more than half 

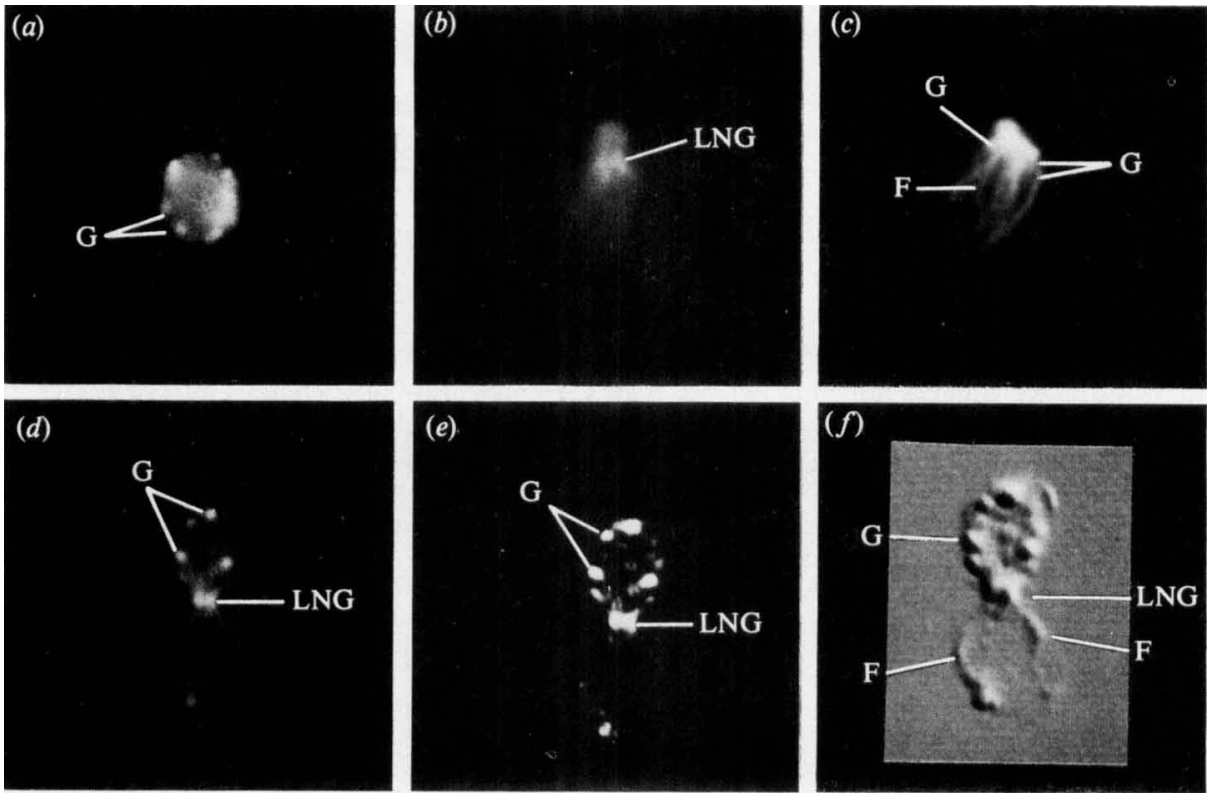

Fig. 2. Fluorescent micrographs of actin distribution in budding cells stained with phalloidin. (a) Edge granules $(G)$ in an unbudded singlet: $(b)$ the large neck granules (LNG) at the junction of daughter cell and early bud; $(c)$ granules clustered at the site of evagination [note the fibres (F) emanating from the cluster]; $(d)$ a cell with large bud exhibiting edge granules and large neck granules; $(e)$ the figure in $(d)$ enhanced using the sharpening convolution on the Image-I Processor (Interactive Video Systems, Inc., Concord, Mass., USA) to accentuate stained actin; $(f)$ the figure in $(d)$ differentially edgeenhanced to accentuate both granules and fibres with a three-dimensional effect. Magnification approximately $1200 \times$.
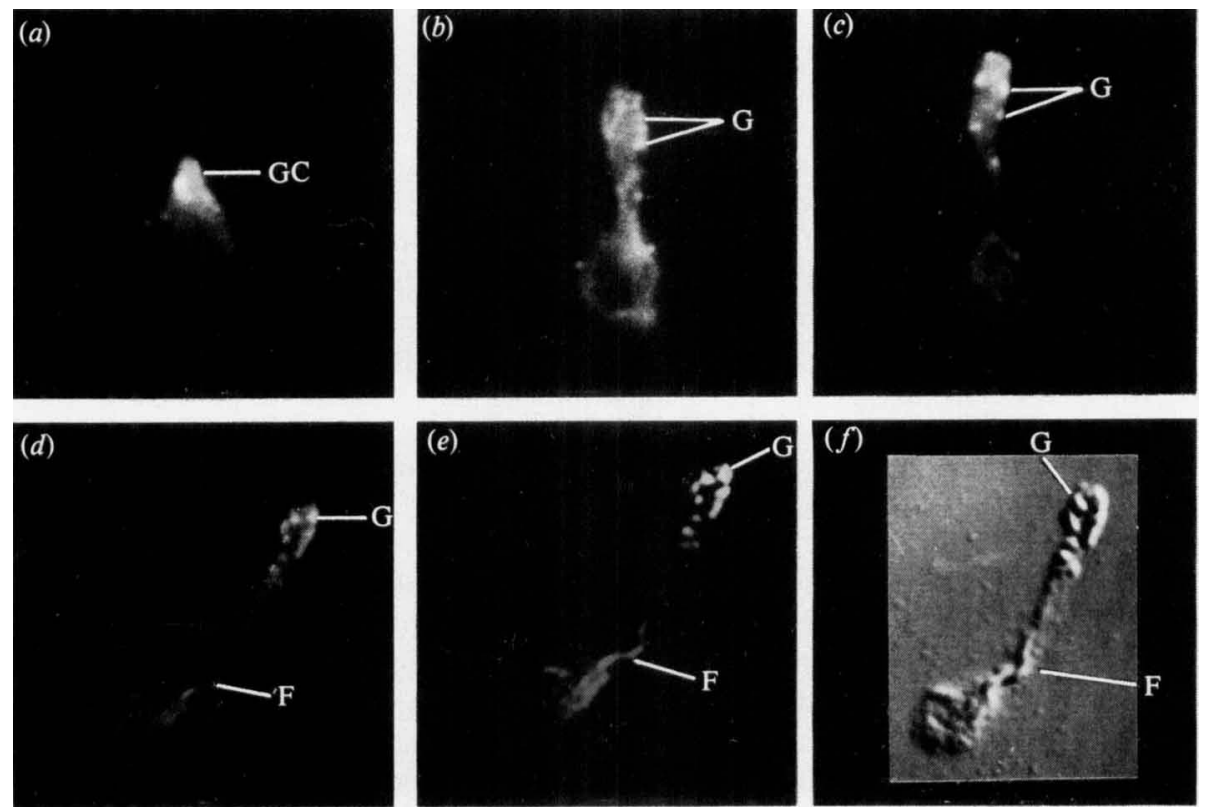

Fig. 3. Fluorescent micrographs of actin distribution in hypha-forming cells stained with phalloidin. (a) Granule cluster (GC) in early evagination; (b) granules (G) clustered in the apical portion of a growing hypha; $(c)$ another example of granules in the apical portion of a growing hypha; $(d)$ large hypha with apical cluster of granules and major fibre $(F)$ winding through hypha; $(e)$ the figure in $(d)$ enhanced using the sharpening convolution on the Image-I Processor to accentuate stained actin; $(f)$ the figure in $(d)$ differentially edge-enhanced to accentuate granules and fibres with a threedimensional effect. Magnification approximately $1200 \times$. 
Table 3. Proportions of small buds ( $p H 4.5)$ and small hyphae ( $p H 6 \cdot 8)$ exhibiting different patterns of actin localization

These data are the combined results of four experiments and are summed for cells with small buds or hyphae at $100,120,140,160$ and $180 \mathrm{~min}$. See Fig. 4 for diagrams of the major patterns. $n$ is the total number of cells scored.

(a) Small buds $(n=159)$

\section{Pattern}

Generally distributed granules in bud Generally distributed granules in bud, large neck granules

Edge granules in bud without directed fibres in bud with directed fibres in bud

Edge granules in bud, large neck granules

without directed fibres in bud with directed fibres in bud Other

Total with generally distributed granules in bud

Total with edge granules in bud (b) Small hyphae $(n=149)$

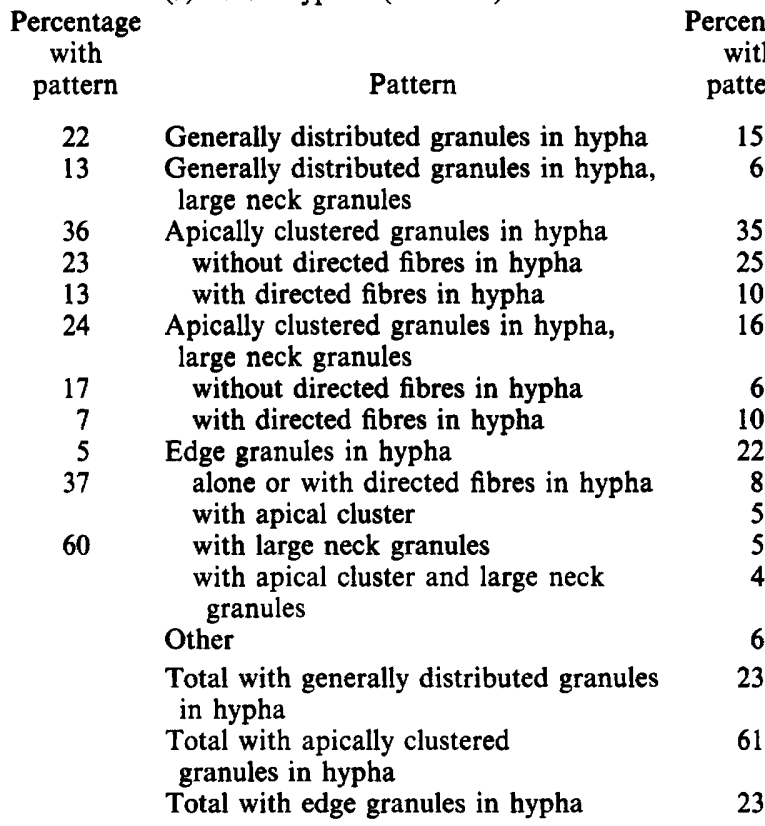

of pre-evaginated cells at either low $\mathrm{pH}$ or high $\mathrm{pH}$, but in less than a quarter of evaginated cells, suggesting that, during evagination, edge granules either disappear or redistribute into the cluster. Conversely, clustered granules were observed in roughly one-third of pre-evaginated cells at low and high pH, but in more than $90 \%$ of evaginated cells at both pH values, suggesting that clustering occurs at the site of evagination, and that the cluster persists during evagination. The appearance of the large neck granules in association with evaginations suggests that they may play a role in evagination. However, the absence of these structures in the region of granule clustering in pre-evaginated cells suggests that they appear after clustering and may therefore not be involved in determining the site of evagination. Finally, it should be pointed out that in all cases where fibres were visible in pre-evaginated or evaginated mother cells, they were oriented towards the cluster, but in pre-evaginated cells with edge granules, the fibres were more random in orientation, suggesting that fibre orientation was either the cause or result of clustering.

\section{Actin localization in small buds and small hyphae}

We next examined the distribution of actin in small buds with diameters less than half that of their mother cell and small hyphae with lengths less than half of the diameter of the mother cell. Although the results for actin localization in pre-evaginated and evaginated cells were similar in budding and hypha-forming populations, actin localization in small buds and hyphae differed significantly, so they will be treated separately in the following discussion. The proportions of small buds and small hyphae exhibiting the different discernible patterns are presented in Table 3 ( $a$ and $b$, respectively).

Small buds. The granules in small buds were distributed into two relatively distinct patterns. In the first pattern (Fig. $4 a$ ), actin granules were generally distributed throughout the bud cytoplasm. Approximately one-third of small buds exhibited this pattern and these particular 


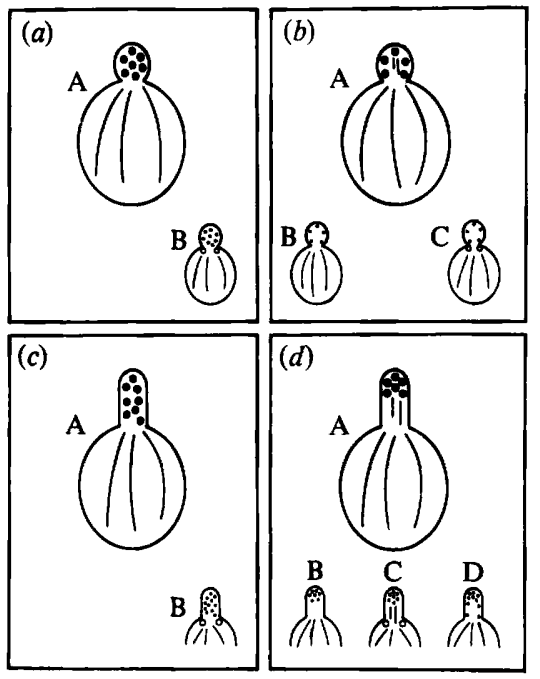

Fig. 4. Diagrams of the major patterns of phalloidin-stained actin in small buds at $\mathrm{pH} 4.5(a, b)$, and in small hyphae at pH 6.8 $(c, d)$. Small budding cells exhibited two major patterns of granule distribution in the bud, generally distributed, or clustered, in the cytoplasm ( $a$ ) or confined to the edge, or cortex, of the cytoplasm $(b)$. Roughly one-third of buds in the former case $(a, \mathrm{~B})$, and about $40 \%$ of buds in the latter case $(b, \mathrm{C})$ contained large neck granules. Roughly one-third of the buds with edge granules exhibited fibres in the bud $(b, \mathrm{~A})$ and over half did not $(b, B)$. In all cases where fibres were evident, they were directed, usually towards the bud apex. Small hyphaforming cells either contained granules distributed throughout the small hypha $(c)$, or confined to the hyphal apex $(d)$. A minority of small hypha-forming cells contained neck granules (c, B and $d, \mathrm{C}$ ), and a minority of small hyphae with apical clusters exhibited edge dots $(d, D)$. The proportions of cells in the different categories are shown in Table 3.

buds represented for the most part the lower range of small bud volumes. In the second pattern (Fig. $4 b$ ), actin granules were localized in the outermost shell, or edge, of the bud cytoplasm; $60 \%$ of small buds exhibited this pattern. Roughly one-third of small buds with generally distributed granules and one-third with edge granules contained large neck granules. In addition, one-third of the small buds with edge granules contained fibres in the bud, which were usually directed apically, but in a few cases they were oriented tangentially to the mother cell position. Over $90 \%$ of all mother cells with small buds contained fibres, which were always directed towards the bud, and $11 \%$ of mother cells contained edge granules, which were evenly distributed between cells with generally distributed bud granules and cells with edge granules in the bud.

The major patterns of actin distribution in small buds can be considered in terms of temporal change. The generally distributed granules in the very smallest buds are similar in appearance to the clustered granules in evaginations. The pattern of edge granules was predominant in the larger buds of the small bud category, suggesting that there is a temporal progression from clustered granules before evagination, to general distribution in the very small bud, to edge localization in larger buds.

Small hyphae. The granules in small hyphae exhibited two major patterns and one minor pattern. In the first pattern (Fig. 4c), actin granules were distributed throughout the hyphal cytoplasm, in a similar fashion to the analogous bud pattern (Fig. $4 a$ ). Approximately a quarter of small hyphae exhibited this pattern. In the second pattern (Fig. $4 d$ ), actin granules were clustered in the apical third of the hypha; $61 \%$ of small hyphae exhibited this pattern. Roughly one-third of small hyphae with generally distributed granules and one-third with apically clustered granules contained large neck granules. In addition, one-third of small hyphae with apically clustered granules contained fibres in the hyphae. These fibres were always directed apically. In a third pattern, granules were localized in the outer shell, or edge, of the hyphal cytoplasm. Almost half of these hyphae also contained an apical granule cluster (Fig. $4 d, \mathrm{D}$ ). Over $90 \%$ of mother cells with a small hypha contained fibres directed towards the hypha, and less than $10 \%$ exhibited edge granules.

As with small buds, the patterns of actin distribution in small hyphae can be considered in terms of temporal change. Again, the generally distributed granules in small hyphae were similar in appearance to the granule clusters in early evaginated cells, and apical clusters were predominant in the larger hyphae of the small hypha category, suggesting a temporal progression from clustered granules in the evagination, to generally distributed granules in the very small hypha, to an apical granule cluster in the slightly longer hypha. The singular 
Table 4. Proportions of medium buds ( $p H 4.5$ ) and medium hyphae ( $p H$ 6.8) exhibiting different patterns of actin localization

These data are the combined results of four experiments and are summed for cells with medium buds or hyphae at 100,120,140,160 and $180 \mathrm{~min}$. See Fig. 5 for diagrams of the major patterns. $n$ is the total number of cells scored.

(a) Medium buds $(n=84)$

Pattern

Edge granules in bud with directed fibres in bud without directed fibres in bud

Edge granules in bud, large neck granules with directed fibres in bud without directed fibres in bud

Generally distributed granules in bud alone

with fibres in bud

with edge granules

Other

with large neck granules

Total with edge granules in bud (b) Medium hyphae $(n=98)$

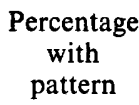

Pattern

Apically clustered granules in hypha with directed fibres in hypha without directed fibres in hypha

Apically clustered granules in hypha, large neck granules with directed fibres in hypha without directed fibres in hypha

Apically clustered granules in hypha, edge granules in hypha with directed fibres in hypha without directed fibres in hypha with large neck granules (with or without fibres in hypha)

Edge granules in hypha (with or without fibres and with or without large neck granules)

Other

Total with apically clustered granules in hypha

Total with edge granules in hypha

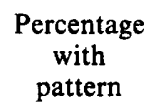

difference, and the first to be noted, between budding and hypha-forming cells, is the predominant pattern of edge granule distribution in the bud versus the predominant pattern of apical granule cluster in a hypha of comparable size.

\section{Actin localization in medium sized buds and hyphae}

Differences in the distribution of actin granules in growing buds and hyphae became even more pronounced when buds with diameters equal to roughly three-quarters of the mother cell diameter and hyphae with lengths between a half and one times the mother cell diameter were compared. The proportions of medium sized buds and medium sized hyphae exhibiting the different discernible patterns are presented in Table 4( $a$ and $b$, respectively).

Medium sized buds. The distribution of actin granules in medium sized buds was relatively uniform in comparison to earlier stages; $86 \%$ exhibited edge granules (Figs $5 a$ and $2 d-f$ ), $26 \%$ more than observed in small buds. Generally distributed granules were observed in only $14 \%$ of medium sized buds, a significant decrease from the $37 \%$ observed in small buds. In addition, one-third of the medium sized buds with generally distributed granules also contained a clear pattern of edge granules, suggesting an intermediate stage between general granule distribution and edge granule distribution, and $25 \%$ contained large neck granules (Figs $5 a, \mathrm{C}$, and $2 d-f$ ), $15 \%$ less than in small buds. As in small buds, roughly $90 \%$ of all mother cells with medium buds contained fibres directed towards the bud and $19 \%$ of the mother cells contained edge granules. Over half of the buds containing edge granules also contained fibres, the majority directed towards the apex. A minority of cells exhibited laterally directed fibres, but in all cases the fibres within an individual bud were aligned with roughly similar polarity.

These results strengthen the conclusion that there is a temporal transition from generally clustered granules in the small bud to edge granules in the medium sized bud.

Medium sized hyphae. As with buds, actin distribution was far more homogeneous in medium sized than in small hyphae; $85 \%$ contained granules clustered in the apical third of the hypha 

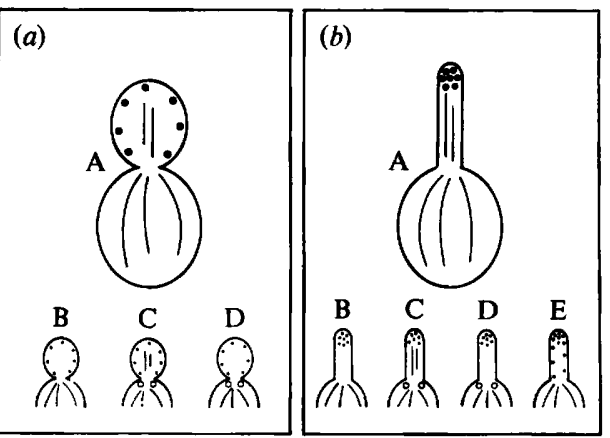

Fig. 5. Diagrams of the major patterns of phalloidinstained actin in medium sized buds $(a)$ and hyphae $(b)$. Of all medium sized buds (with diameters roughly threequarters that of their mother cell) $86 \%$ contained edge granules $(a)$. The majority contained directed fibres in the bud, usually directed towards the apex $(a, \mathrm{~A})$. Significant proportions contained no bud fibres $(a, B)$, large neck granules with bud fibres $(a, C)$, or large neck granules without bud fibres $(a, \mathrm{D})$. Of all medium sized hyphae $85 \%$ contained an apical cluster of granules $(b)$. The majority contained directed fibres in the hypha, always directed towards the apex $(b, A)$. Significant proportions contained no hyphal fibres $(b, \mathrm{~B})$, large neck granules with $(b, \mathrm{C})$ or without $(b, \mathrm{D})$ hyphal fibres, and edge granules in the hypha $(b, \mathrm{E})$. The proportions of cells in the different categories are shown in Table 4.

(Figs $5 b$ and $3 b, c$ ), more than the $61 \%$ in small hyphae, and only $1 \%$ of medium sized hyphae contained generally distributed granules, compared to $23 \%$ in small hyphae. Of medium sized hyphae with apical clusters $21 \%$ also exhibited edge granules (Fig. $5 b$, E). It is noteworthy that the proportion of medium sized buds with edge granules was almost identical to the proportion of medium sized hyphae with apical clusters.

The proportion of medium sized hyphae containing large neck granules was $21 \%$ and the proportion of mother cells with edge granules was $13 \%$, both proportions little changed from the small hypha population. However, a new pattern of fibre orientation appeared in a minority of mother cells. Although $93 \%$ of mother cells contained fibres, $7 \%$ were randomly directed, a pattern rarely observed in cells with small hyphae or in cells with small or medium sized buds. In these latter cases, mother cell fibres were almost always oriented towards the daughter hypha or bud, respectively.

\section{Actin localization in large buds and hyphae}

The major patterns of granule and fibre distribution established in small and medium sized buds continued in the majority of large buds, with diameters close to that of the mother cell, and the patterns in small and medium sized hyphae continued in the majority of large hyphae, with lengths greater than the diameter of the mother cell. However, new patterns appeared in the diverging populations which appeared to be related to the different modes of growth compartmentation. The proportions of large buds and large hyphae exhibiting the different discernible patterns are shown in Table 5( $a$ and $b$, respectively).

Large buds. Roughly two-thirds of large buds contained edge granules (Fig. 6a) and the majority of these buds had fibres directed apically. However, one-fifth of large buds contained a cluster of granules at or near the apex (Fig. 6b), a pattern not observed in small or medium sized buds. Changes in the patterns of granules were also evident in mother cells of large buds. First, one-third contained edge granules, compared to one-fifth in medium sized buds and one-tenth in small buds. Second, $6 \%$ of mother cells contained a cluster of granules positioned roughly onequarter of the cell's semi-circumference away from the mature bud (Fig. 6c).

The appearance of apical granule clusters in mature buds correlates both in space and time to secondary bud formation on the matured bud. In addition, the position of the granule cluster in mother cells correlates with the expected position of the secondary bud on the mother cell (Soll \& Herman, 1983). The increase in edge granules in the transition from small to medium sized buds, and their subsequent decrease in large buds suggests that a temporal programme of edge granules, granule clustering and subsequent evagination functions during secondary budding. This sequence was also suggested during the programme of initial budding (see previous sections).

Large hyphae. Over $90 \%$ of large hyphae contained granule clusters in the apical portion of the hypha (Figs $6 d-f$ and $3 d-f$ ). One-third also contained edge granules in the hyphae (Fig. 6e). The 

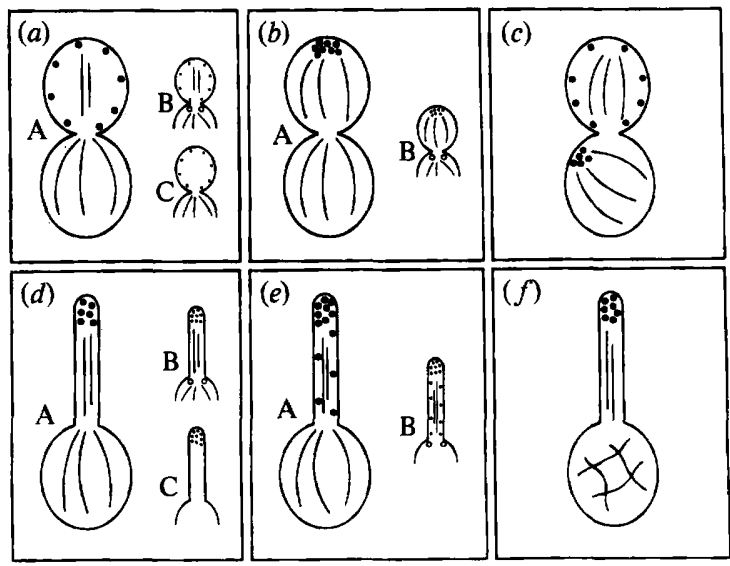

Fig. 6. Diagrams of the major patterns of phalloidin-stained actin in large buds $(a-c)$ and hyphae $(d-f)$. Of all large sized buds (with diameters close to that of the mother cell) $69 \%$ contained edge granules. The majority contained directed fibres in the bud usually directed towards the apex $(a, \mathrm{~A})$. Of large buds $19 \%$ contained a cluster of granules at or near the apex $(b, A)$. Of the mother cells $6 \%$ contained a cluster of granules positioned roughly one-quarter of the cell's semi-circumference away from the mature bud (c). Of the large hyphae $95 \%$ contained granule clusters in the apical portion of the hypha $(d)$. The majority of hyphae contained fibres oriented towards the apex $(d-f)$. Of the large hyphae $34 \%$ contained edge granules in the hyphae $(e)$. Of the mother cells $9 \%$ contained randomly directed fibres $(f)$. The proportions of cells in the different categories are shown in Table 5 .

\section{Table 5. Proportions of large buds ( $p H 4.5)$ and large hyphae ( $p H 6.8)$ exhibiting different patterns of actin localization}

These data are the combined results of four experiments and are summed for cells from 100 to $180 \mathrm{~min}$ development time. See Fig. 6 for diagrams of the major patterns. Large buds had diameters between three-quarters and one times that of mother cells and large hyphae had lengths one times or more that of mother cells. $n$ is the total number of cells scored.

(a) Large buds $(n=74)$

\section{Pattern}

Edge granules in bud with directed fibres in bud without directed fibres in bud

Edge granules in bud, large neck granules with directed fibres in bud without directed fibres in bud

Apical cluster in bud with directed fibres in bud without directed fibres in bud with large neck granules (with or without fibres in bud)

Other: fibres alone, fibres and neck granules, generally distributed granules

Total with edge granules in bud

Total with apical cluster in bud

Total with cluster in mother cell and fibres directed to cluster (b) Large hyphae $(n=100)$

Percentage
with
pattern

49

34

15

20

15

5

19

10

5

4

12

69
Apically clustered granules in hypha with directed fibres in hypha without directed fibres in hypha

Apically clustered granules in hypha, large neck granules with directed fibres in hypha without directed fibres in hypha

Apically clustered granules and edge granules in hypha with directed fibres in hypha without directed fibres in hypha

Apically clustered granules and edge granules in hypha, large neck granules with directed fibres in hypha without directed fibres in hypha

Other: fibres alone, generally distributed granules, edge granules alone or with fibres

Total with apically clustered granules in hypha

Total with edge granules in hypha

Total with randomly oriented fibres Percentage
with pattern 


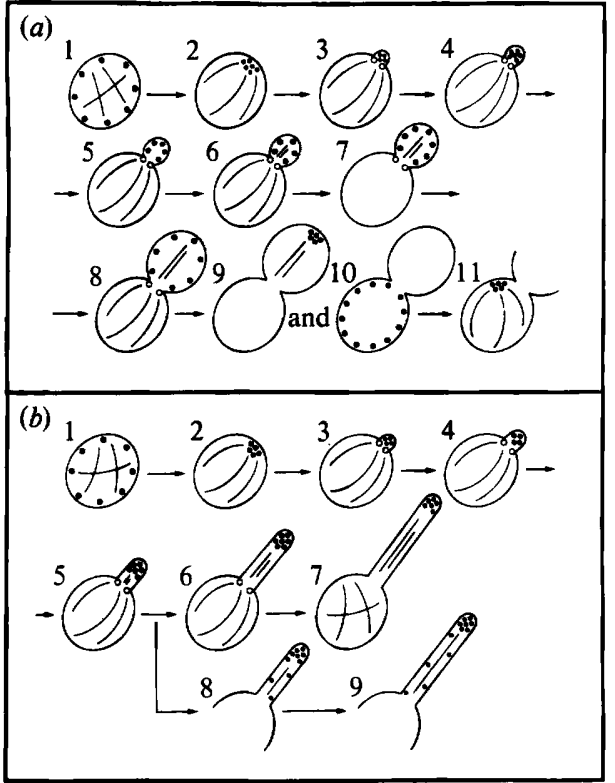

Fig. 7. Models for the dynamic changes in actin localization during bud $(a)$ and hypha $(b)$ formation under the regime of pH-regulated dimorphism. These models are considered in detail in the Discussion.

majority of hyphae contained fibres oriented towards their apex (Fig. $3 d-f$ ). Of the mother cells $9 \%$ contained randomly oriented fibres, and $2 \%$ exhibited a cluster of granules at a distance roughly one-quarter of the mother cell's circumference from the original hypha, the position of a small projection which represents an apparently incomplete evagination in a small proportion of hypha-forming cells under the regime of pH-regulated dimorphism (D. R. Soll, unpublished observation).

\section{DISCUSSION}

To compare the dynamics of actin distribution between bud and hypha formation in Candida albicans, we used a fluorescent conjugate of phalloidin, a phallotoxin of the mushroom Amanita phalloides, which specifically stains filamentous actin (Wulf et al., 1979) and effectively stains the filamentous actin of yeast (Kilmartin \& Adams, 1984; Adams \& Pringle, 1984; Hoch \& Staples, 1983). By scoring the proportions of cells which exhibited different patterns of actin distribution at five stages of bud or hyphal development, we were able to extrapolate a temporal sequence of changes in actin distribution (Fig. 7), which is similar during the early stages of evagination in the budding and hypha-forming populations, but which differs markedly between growing buds and hyphae.

A temporal model of actin localization during bud formation. When stationary phase cells are released into fresh medium at $\mathrm{pH} 4.5$ to induce bud formation, they are homogeneously positioned as unbudded singlets in $\mathrm{Gl}$ of the cell cycle (Soll, 1984). These cells appear to contain no filamentous or granular actin. Just before evagination, roughly two-thirds of the cells exhibit edge granules and randomly directed fibres (Fig. $7 a, 1)$ and one-third exhibit a cluster of granules with cytoplasmic fibres directed towards the cluster (Fig. 7a, 2). Upon evagination, all cells contain a granule cluster in the evagination (Fig. $7 a, 3$ and 4) and fibres directed towards the cluster, or evagination, suggesting that there is a temporal transition from unevaginated cells with edge granules and randomly directed fibres, to unevaginated cells with a granule cluster and directed fibres, to evaginated cells with granules clustered in the early evagination (Fig. $7 a$, 1-4).

At the time of evagination, an actin dense structure composed of two large granules or a bar appears at the junction of mother cell and evagination. Since the granule cluster marks the position of evagination and precedes the large neck granules, it is unlikely that the large neck 
granules are involved in positioning, although they may be involved in the outpocketing process. The reason why the large neck granules are not observed in more than roughly one-third of evaginating or budded cells in not clear, but may reflect either instability during fixation or transiency during the budding cycle.

As the evagination grows, the clustered granules first fill the cytoplasm (Fig. 7a, 4), then either redistribute into the cortex of the cytoplasm or disappear as new granules form in the cortex (Fig. 7a, 5 and 6). With the appearance of edge granules, directed fibres are apparent in the bud cytoplasm, usually but not always directed apically. With continued bud growth, this pattern of edge granules and fibres is maintained (Fig. $7 a, 5-8$ ). With bud maturation, a cluster of granules again forms in the cytoplasmic cortex of the bud (Fig. 7a,9). In the mother cell of mature buds, edge granules increase and granule clusters appear (Fig. $7 a, 10$ and 11, respectively). Presumably, this reflects a progression from edge granules to clustered granules in a similar fashion to that observed during initial evagination. The position of new clusters in mature buds and their mother cells in both cases is at the predicted site of secondary budding. Interestingly, when edge granules form in the mother cells of mature buds, fibres once again appear randomly directed, suggesting that they become directed in a mother cells when a granule cluster is present.

A temporal model of actin localization during hypha formation. When stationary phase cells are released into fresh medium at $\mathrm{pH} 6.8$ to induce hypha formation, they are again positioned as unbudded singlets in G1 of the cell cycle (Soll, 1984). As for cells released into medium at pH 4.5 , the cells initially contain no filamentous or granular actin, then exhibit edge granules and random fibres (Fig. $7 b, 1$ ). Just before evagination, granules cluster (Fig. $7 b, 2$ ), and upon evagination fill the cytoplasm of the incipient hypha (Fig. $7 b, 3$ and 4). However, in contrast to the average budding cell (Fig. 7a, 5-7), the granules do not then redistribute into the cortex. Rather, they remain in the apical region (Fig. 7b, 5-7). In some cases, granules are present in the cortex of the entire hypha but usually at a density far below that in the apical region of the same hypha (Fig. $7 b, 8$ and 9). In all hyphae, fibres are directed towards the apex.

Actin distributions, cell shape and the zones of cell wall expansion. Kilmartin \& Adams (1984) presented evidence that during the growth of the bud of Saccharomyces uvarum, actin granules are first localized at the junction of mother cells and evagination, but as the daughter bud grows, granules disappear from the junction and reappear at the bud apex. Interestingly, the bud of $S$. uvarum is quite elongated, almost tubular. In contrast, Adams \& Pringle (1984) presented evidence that actin granules are distributed throughout the cortex of a growing bud of wild-type $S$. cerevisiae. Interestingly, the buds of $S$. cerevisiae are relatively round. In addition, Adams \& Pringle (1984) found that cell division cycle mutants cdc3, cdc10, cdc11, cdc12 and cdc4 formed elongated buds at restrictive temperature and had condensed actin in the bud apices. These results correlate quite nicely with our data on buds and hyphae in C. albicans, and together suggest that the formation of an elongated daughter cell correlates with condensations of actin granules in the daughter cell apex, and that the formation of a round daughter cell correlates with actin granules distributed throughout the cortex of the cytoplasm.

The distribution of actin in the budding cycle has been implicated in cell wall biogenesis. Novick \& Botstein (1985) have demonstrated that mutations in the structural gene of yeast actin result in disruption of both the normal actin pattern and the normally localized deposition of chitin, inhibition of invertase secretion, accumulation of vesicles, and increased osmotic sensitivity. Although it is not clear how defective actin results in this pleiotropic effect, it is suggested that the loss of actin organization results in disorganized wall development. Recently, we demonstrated that the zones of wall expansion differ significantly between bud and hypha (Staebell \& Soll, 1985; Soll et al., 1985). The most notable difference is that the growth of the bud wall depends to a significant extent upon general wall expansion, but in contrast the growth of the hyphal wall depends almost entirely upon an apical zone of wall expansion (Staebell \& Soll, 1985). It therefore may not be coincidental that, in the growing bud, actin granules are distributed throughout the cytoplasmic cortex and, in the growing hypha, actin granules are localized in the apex. It is therefore of immediate importance to know the ultrastructure and function of these actin granules. 
We are indebted to Dr Jim Lin of the University of Iowa and to Dr Robert Goldman of Northwestern University School of Medicine for their help in working out the methods for fluorescent staining. We thank Edward Voss for assistance with the Image-I Processor. We are also indebted to Lee Mitchell, Paula Jennings and Kimberly Drollinger for help in organizing the manuscript. This research was supported by grant number PCM$\mathbf{8 2 0 2 3 8 0}$ from the National Science Foundation awarded to D.R.S. and by a grant from the University of Iowa Research Foundation. J.M.A. was supported by National Research Service Award number HD07216 from the National Institutes of Health.

\section{REFERENCES}

Adams, A. E. M. \& Pringle, J. R. (1984). Relationship of actin and tubulin distribution to bud growth in wild-type and morphogenetic-mutant Saccharomyces cerevisiae. Journal of Cell Biology 98, 934-945

ANDERSON, J. M. \& SolL, D. R. (1984). Effects of zinc on stationary-phase phenotype and macromolecular synthesis accompanying outgrowth of Candida albicans. Infection and Immunity 46, 13-21.

BeDELL, G. \& Soll, D. R. (1979). The effects of low concentration of zinc on the growth and dimorphism of Candida albicans: evidence for zinc-resistant and zinc-sensitive pathways for mycelium formation. Infection and Immunity 26, 348-354.

BEDELL, G., WERTH, A. \& Soll, D. R. (1980). The regulation of nuclear migration and division during synchronous bud formation in released stationary phase cultures of the yeast Candida albicans. Experimental Cell Research 127, 103-113.

Buffo, J., Herman, M. \& Soll, D. R. (1984). A characterization of pH-regulated dimorphism in Candida albicans. Mycopathologia 85, 21-30.

Herman, M. A. \& Soll, D. R. (1984). A comparison of volume growth during bud and mycelium formation in Candida albicans: a single cell analysis. Journal of General Microbiology 130, 2219-2228.

Hoch, H. C. \& STAPLes, R. C. (1983). Visualization of actin in situ by rhodamine-conjugated phalloin in the fungus Uromyces phaseoli. European Journal of Cell Biology 32, 52-58.

Kilmartin, J. V. \& AdAmS, A. E. M. (1984). Structural rearrangements of tubulin and actin during the cell cycle of the yeast Saccharomyces. Journal of Cell Biology 98, 922-933.

Lee, K. L., BuCKLey, H. R. \& CAMPbell, C. C. (1975). An amino acid liquid synthetic medium for development of mycelial and yeast forms of Candida albicans. Sabouraudia 13, 148-153.

Mitchell, L. \& SolL, D. R. (1979a). Commitment to germ tube or bud formation during release from stationary phase in Candida albicans. Experimental Cell Research 120, 167-179.

MitChell, L. \& SOLL, D. R. (1979b). Temporal and spatial differences in septation during synchronous mycelium and bud formation by Candida albicans. Experimental Mycology 3, 298-309.

Novick, P. \& Botstein, D. (1985). Phenotypic analysis of temperature-sensitive yeast actin mutants. Cell $\mathbf{4 0}$, 405-416.
SolL, D. R. (1984). The cell cycle and commitment to alternate cell fates in Candida albicans. In The Microbial Cell Cycle, pp. 143-162. Edited by P. Nurse \& E. Streiblova. Boca Raton, Florida: CRC Press.

SOLL, D. R. (1985a). The role of zinc in Candida dimorphism. In Current Topics in Medical Mycology, vol. 1, pp. 258-285. Edited by M. R. McGinnis. New York: Springer-Verlag.

Soll, D. R. (1985b). Candida albicans. In Fungal Dimorphism: with Emphasis on Fungi Pathogenic for Humans, pp. 167-195. Edited by P. Szaniszlo. New York: Plenum Press.

Soll, D. R. \& BEDELL, G. (1978). Bud formation and the inducibility of pseudo-mycelium outgrowth during release from stationary phase in Candida albicans. Journal of General Microbiology 108, 173180.

Soll, D. R. \& Herman, M. A. (1983). Growth and the inducibility of mycelium formation in Candida albicans: a single-cell analysis using a perfusion chamber. Journal of General Microbiology 129, 2809 2824.

Soll, D. R., Stasi, M. \& Bedell, G. W. (1978). The regulation of nuclear migration and division during pseudo-mycelium outgrowth in the dimorphic yeast Candida albicans. Experimental Cell Research 116, 207-215.

Soll, D. R., Bedell, G., Thiel, J. \& Brummel, M. (1981). The dependency of nuclear division on volume in the dimorphic yeast Candida albicans. Experimental Cell Research 133, 55-62.

Soll, D. R., Herman, M. A. \& Staebell, M. A. (1985). The involvement of cell wall expansion in the two modes of mycelium formation of Candida albicans. Journal of General Microbiology 131, 23672375 .

Staebell, M. \& Soll, D. R. (1985). Temporal and spatial differences in cell wall expansion during bud and mycelium formation in Candida albicans. Journal of General Microbiology 131, 1467-1480.

Wulf, E., Deboben, A., Bautz, F. A., Faulstich, H. \& WiEland, Th. (1979). Fluorescent phallotoxin, a tool for the visualization of cellular actin. Proceedings of the National Academy of Sciences of the United States of America 76, 4498-4502. 